\title{
PENERAPAN PRINSIP GREEN BUILDING COUNCIL DITINJAU DARI ASPEK MATERIAL DAN PENENTUAN KRITERIA PEMILIHAN MATERIAL KONSTRUKSI
}

\author{
Melchior Bria ${ }^{1}$, Mathelda CH. Mauta ${ }^{2}$, Theresia A. Bria ${ }^{3}$
}

\begin{abstract}
Abstrak :
Salah satu agenda yang diusulkan dalam penerapan green construction adalah promosi sustainable construction untuk penghematan bahan dan pengurangan limbah (bahan sisa) serta kemudahan pemeliharaan bangunan pasca konstruksi (LPJKN, 2007). Untuk itu dalam penelitian ini bermaksud mengkaji kesesuaian penggunaan material konstruksi pada bangunan gedung bertingkat di Kota Kupang dan sekitarnya dengan standar green BUILDING COUNCIL serta mengidentifikasi kriteria yang digunakan untuk pengambilan keputusan penentuan jenis material. Penelitian dilakukan terhadap bangunan bertingkat di Kota Kupang, Ruko, Sekolah, Perkantoran dan Hotel. Hasil menunjukkan secara umum, penerapan prinsip green building council Indonesia dalam penggunaan material konstruksi pada bangunan gedung di Kota Kupang masih belum dilakukan secara baik. Hal ini ditunjukkan dengan hasil survey menunjukkan bahwa 55\% dari bangunan gedung di Kota Kupang belum optimal dalam penggunaan material berdasarkan Green Building Council Indonesia. Sedangkan kriteria yang dapat digunakan sebagai dasar penentuan jenis material konstruksi adalah Gambar rencana dan spesifikasi teknis sesuai peruntukan; Metode kerja; Penggunaan material lama; Penggunaan material terbarukan; Penggunaan kayu bersertifikat; Penggunaan material off site (prefabrikasi); dan Penggunaan material dari radius $1000 \mathrm{~km}$ dan berasal dari lokal.
\end{abstract}

Kata Kunci : Green, Building, Material.

\section{PENDAHULUAN}

Konsep pembangunan berkelanjutan mencakup tiga pilar utama yang saling terkait dan saling menunjang yakni pembangunan ekonomi, pembangunan sosial dan pelestarian lingkungan hidup. Oleh karena itu dalam KTT Bumi, 1992 disepakati pola pembangunan baru yang diterapkan secara global yang disebut dengan Environmentally Sound and Sustainable Development (ESSD). Di Indonesia dikenal dengan Pembangunan Berkelanjutan yang Berwawasan Lingkungan (PBBL) yang didefinisikan sebagai pembangunan untuk memenuhi kebutuhan saat ini tanpa mengurangi kemampuan generasi mendatang untuk memenuhi kebutuhannya. Salah satu turunan dari PBBL adalah dokumen konstruksi Indonesia 2030 (Ervianto, 2012)

Dalam dokumen Konstruksi Indonesia 2030, dinyatakan bahwa konstruksi Indonesia mesti berorientasi untuk tidak menyumbangkan terhadap kerusakan lingkungan namun justru menjadi pelopor perbaikan dan peningkatan kualitas lingkungan. Salah satu agenda yang diusulkan adalah melakukan promosi sustainable construction untuk penghematan bahan 


\section{\begin{tabular}{l|llll}
38 & JUTEKS & Jurnal Teknik Sipil & Volume 2 & Nomor 1 April 2017
\end{tabular}}

dan pengurangan limbah (bahan sisa) serta kemudahan pemeliharaan bangunan pasca konstruksi (LPJKN, 2007). Council International du Batument, (1994) menyatakan bahwa tujuan sustainable construction adalah menciptakan bangunan berdasarkan disain yang memperhatikan ekologi, menggunakan sumberdaya alam secara efisien, dan ramah lingkungan selama operasional bangunan. Du Plessis (2002) menyatakan bahwa bagian dari sustainable construction adalah green construction yang merupakan proses holistik yang bertujuan untuk mengembalikan dan menjaga keseimbangan antara lingkungan alami dan buatan. USEPA (2010) mendefinisikan green construction merupakan praktik membangun dengan menerapkan proses yang memperhatikan lingkungan dan efisiensi sumber daya sepanjang siklus hidup bangunan dari tapak untuk perencanaan, konstruksi, operasi, pemeliharaan, renovasi, dan dekonstruksi.

Fakta bahwa: (a) dengan bertambahnya jumlah infrastruktur maka cadangan alam akan berkurang dan jumlah limbah sebagai hasil proses konstruksi meningkat; (b) meningkatnya jumlah limbah maka beban lingkungan akan semakin besar. Oleh karena itu perlu dilakukan kajian yang lebih komprehensif untuk menemukan cara-cara pembangunan yang ramah lingkungan. Salah satu aspek penting yang dalam pembangunan konstruksi adalah penggunaan material konstruksi yang berkelanjutan dan pengaruhnya terhadap lingkungan (Ervianto, 2012).

Sejalan dengan hal tersebut di atas maka penelitian ini bermaksud mengkaji kesesuaian penggunaan material konstruksi pada bangunan gedung bertingkat di Kota Kupang dan sekitarnya dengan standar green construction.

Green Building adalah suatu bangunan yang menerapkan prinsip lingkungan dalam perancangan, pembangunan, pengoperasian dan pengelolaanya dan aspek penting penanganan dampak perubahan iklim (Peraturan Menteri Negara Lingkungan Hidup Nomor 08 Tahun 2010 Pasal 1 Ayat 1).
Menurut Green Building Council Indonesia (2010), Green building adalah bangunan baru yang direncanakan dan dilaksanakan atau bangunan sudah terbangun yang dioperasikan dengan memperhatikan faktor-faktor lingkungan / ekosistem dan memenuhi kinerja: bijak guna lahan, hemat air, hemat energi, hemat bahan, kurangi limbah kualitas udara dalam ruangan. Green Building adalah bangunan yang harus hemat air, efisiensi energi, mengkonversi sumber daya alam, mengurangi limbah, memberikan ruang lebih sehat dibandingkan dengan bangunan konvensional (India Green Building Council, 2012)

Bangunan dapat dikatakan sebagai green building jika memenuhi kriteria green building. Di Indonesia kriteria tersebut telah ditetapkan oleh Menteri Lingkungan Hidup nomor 8 Tahun 2010, antara lain :

1.Menggunakan material ramah lingkungan, diantaranya material bangunan bersertifikat dan material bangunan lokal.

2.Terdapat fasilitas, sarana, dan prasarana untuk konservasi sumber daya air dalam bangunan gedung, diantaranya mempunyai sistem pemanfaatan air yang dikuantifikasi, menggunakan sumber air yang memperhatikan konservasi sumber daya air, mempunyai sistem pemanfaatan air hujan.

3.Terdapat sarana dan prasarana konservasi dan diservikasi energi meliputi penggunaan sumber energi alternatif, menggunakan sistem pencahayaan dan pengkondisian udara buatan yang hemat energi.

4. Menggunakan bahan yang merupakan bukan bahan perusak Ozon.

5.Terdapat fasilitas sarana dan prasarana pengelolaan air limbah domestik.

6.Fasilitas pemilahan sampah.

7.Memperhatikan aspek kesehatan bagi penghuni bangunan meliputi sistem sirkulasi udara, memaksimalkan penggunaan sinar matahari.

8.Terdapat fasilitas, sarana, dan prasarana pengelolaan tapak berkelanjutan, meliputi adanya ruang terbuka hijau mempertimbangkan variabilitas iklim mikro dan perubahan 
iklim, perencanaan pengelolaan gedung sesuai dengan tata ruang

9.Terdapat fasilitas, sarana dan prasarana untuk mengantisipasi bencana, meliputi mempunyai sistem peringatan dini, menggunakan material yang tahan terhadap iklim.

Hermawan (2013), menyatakan bahwa penggunaan material konstruksi merupakah salah satu sumber emisi karbon dioksida. Semen, keramik dan baja merupakan tiga material konstruksi yang menghasilkan emisi karbon dioksida terbesar. Besarnya emisi karbon dioksida dapat terjadi pada semua tahapan yang ada pada analisis daur hidup. Oleh karena itu, dalam analisis daur hidup diperlukan upaya untuk memonitor keluaran emisi karbon dioksida pada setiap tahapan konstruksi sehingga dapat berkontribusi untuk mewujudkan konstruksi yang berkelanjutan.

Ervianto (2012) dalam penelitiannya yang bertujuan mengkaji cara-cara pembangunan yang ramah lingkungan, lebih difokuskan pada aspek material konstruksi yang berkelanjutan dimana kajian dilakukan pada rencana pembangunan jembatan Selat Sunda, diperoleh hasil bahwa emisi yang ditimbulkan oleh material konstruksi sebesar 1.972.613 ton CO2 ekivalen. Selain itu perlu perhatian pada saat umur kelayakan berakhir maka akan menimbulkan limbah dalam jumlah sangat besar sehingga perlu waste management plan.

\section{METODE PENELITIAN}

Penelitian ini dilakukan di wilayah Kota Kupang dan sekitarnya dimana obyek studi adalah bangunan gedung bertingkat baik itu gedung kantor, sekolah, rumah sakit, tempat ibadah, rumah toko, supermarket yang sedang dibangun maupun yang sudah dibangun.

Sedangkan yang dimaksud dengan bangunan bertingkat dalam penelitian ini adalah bangunan yang menggunakan konstruksi kayu, beton atau baja yang terdiri dari minimal dua lantai dan berlokasikan di Kota Kupang dan sekitarnya. Bangunan bertingkat yang dipilih adalah terdiri dari bangunan fasilitas umum seperti gedung sekolah, rumah sakit, perkantoran dan fasilitas umum lainnya, pusat perbelanjaan, dan Hotel. Sampel dalam penelitian diambil secara acak dari populasi rumah bertingkat kategori nondomestik.

Dalam survey ini menggunakan kuesioner yang berisikan pertanyaan yang akan dijawab oleh responden. Responden adalah pemilik bangunan atau yang ditunjuk oleh pemilik bangunan atau orang yang ditugaskan untuk melaksanakan pembangunan fisik yang mewakili suatu organisasi/instansi/perusahaan.

Kuesioner berisi pertanyaan seputar penggunaan material konstruksi pada bangunan menggunakan standar Greenship Existing Building yang dikeluarkan oleh Green Building Council Indonesia Versi 1.0.

Selanjutnya, kriteria/faktor disusun berdasarkan kajian pustaka dan hasil identifikasi kondisi eksisting. Rumusan kriteria ini kemudian dijadikan bahan penyusun kuesioner penentuan kriteria. Kuesioner didesain sedemikian rupa sehingga pilihan jawaban akan menghasilkan skor berdasarkan tingkat kepentingannya terhadap substansi pertanyaan kuesioner.

Skor yang dipakai dalam kuesioner adalah menggunakan angka dari 1 - 5 untuk menyatakan tingkatan pengaruh berdasarkan skala Likert, yaitu :

- Skor 5 untuk menyatakan tingkatan sangat penting

- Skor 4 untuk menyatakan tingkatan penting

- Skor 3 untuk menyatakan tingkatan cukup penting

- Skor 2 untuk menyatakan tingkatan tidak penting

- Skor 1 untuk menyatakan tingkatan sangat tidak penting

Responden yang direncanakan dalam penelitian ini adalah

- Orang yang mengerti benar terhadap masalah yang dibahas.

- Merasakan akibat dari suatu masalah.

- Mempunyai kepentingan terhadap masalah tersebut. 
Responden adalah para pengambil kebijakan dan penyusun program pemeliharaan jalan.

Hasil dari survey kuesioner penentuan kriteria tersebut selanjutnya diuji menggunakan uji statistik untuk menentukan subkriteria yang akan dipakai dalam penentuan prioritas pemeliharaan jalan. Perhitungan Statistik ini menggunakan Program SPSS for Windows versi 12.0.

Kriteria yang akan digunakan pada model hierarki adalah kriteria yang memenuhi syarat Valid dan Reliabel. Validitas diukur dengan mengkorelasikan skor faktor dan skor total yang selanjutnya dibandingkan dengan nilai tabel korelasi Pearson. Jika nilai koefisien korelasi product moment dari suatu pertanyaan tersebut berada di atas nilai tabel korelasi Pearson, maka pertanyaan tersebut signifikan. Sedangkan jika menggunakan nilai $p$-value maka jika $p$-value mempunyai nilai di bawah taraf signifikansi $\alpha$ maka pertanyaan tersebut signifikan. Sedangkan Pengujian reliabilitas instrumen dilakukan secara eksternal maupun internal. Salah satu teknik yang dilakukan adalah teknik belah dua dari Spearman Brown (spilt half). Rumus yang digunakan adalah:

$$
r_{i}=\frac{2 r_{b}}{1+r_{b}}
$$

Keterangan :

$r i=$ relabilitas internal seluruh instrumen

$r b=$ korelasi product moment antara belah pertama dan kedua

Selain itu, reliabilitas instrumen dapat pula diukur menggunakan analisa reliabilitas - scale (alpha) dengan bantuan program SPSS 12.0. Hipotesis yang dibangun adalah :

$\mathrm{H}_{0}$ : Skor butir berkorelasi positif dengan komposit faktornya (reliabel)

$\mathrm{H}_{1}$ : Skor butir tidak berkorelasi positif dengan komposit faktornya (tidak reliabel)

Jika $r$ hasil (alpha) $>r$ korelasi maka terima Ho

Jika $r$ hasil (alpha) $<$ r korelasi maka tolak Ho

- Jumlah frekuensi jawaban sangat penting dan penting lebih besar $50 \%$

- Rata-rata nilai kriteria minimal 3,5 pada skala Likert 1 (sangat tidak penting) sampai 5 (sangat penting) dimana :

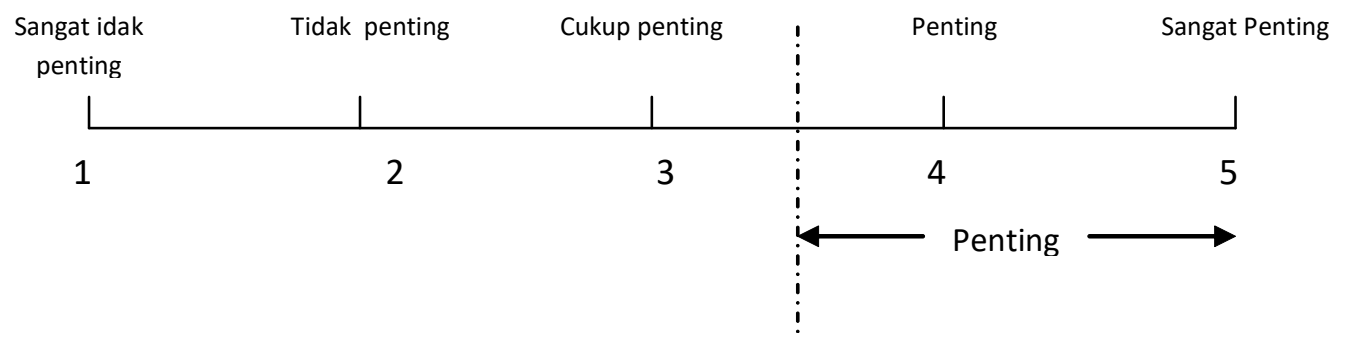

- Uji beda rata-rata (compare mean), uji ini dilakukan untuk mengetahui adanya perbedaan yang signifikan di antara item/ subkriteria dalam satu kriteria. Uji ini dibutuhkan karena dalam model hirarki hanya digunakan subkriteria yang tingkat kepentingannya tinggi. Apabila dalam satu kriteria terdapat beda yang signifikan maka dilanjutkan dengan uji LSD (Lead Significant Different) untuk mendapatkan tingkat signifikansi antar-subkriteria. Semua uji

statistik ini menggunakan program SPSS for Windwos 12,0.

\section{PEMBAHASAN}

\section{Identifikasi Bangunan Bertingkat}

Bangunan bertingkat di Kota Kupang umumnya merupakan bangunan yang struktur utamanya terdiri dari campuran beton bertulang dan rangka baja. Dalam penelitian ini bangunan yang diidentifikasi adalah bangunan bertingkat rendah minimal 2 lantai dan maksimal 5 lantai. 
Jumlah bangunan yang diidentifikasi adalah 30 bangunan bertingkat, umumnya adalah bangunan ruko (20 unit), sekolah dan perkantoran (5 unit) dan hotel/restoran (5 unit)

Adapun kriteria yang akan digunakan untuk mengidentifikasi bangunan adalah berdasarkan green building council khususnya pada penggunaan material konstruksi apakah sesuai dengan standar green building council indonesia, yaitu:

1. Tidak menggunakan refrigeran HCFC untuk sistem AC.

2. Menggunakan material lama sebesar minimum $15 \%$ dari total biaya material yang digunakan.

3. Menggunakan material lama sebesar minimum $30 \%$ dari total biaya material yang digunakan

4. Menggunakan material lama sebesar minimum $45 \%$ dari total biaya material yang digunakan.

5. Menggunakan material dari sumber terbarukan sebesar minimum $20 \%$ dari total biaya matrial yang digunakan.

6. Menggunakan material dari sumber terbarukan sebesar minimum $20 \%$ dari total biaya material yang digunakan.

7. Menggunakan material yang proses produksinya memiliki sistem manajemen lingkungan sebesar minimum $30 \%$ dari total biaya material yang gunakan.

8. Penggunaan kayu bersertifikat legal.

9. Penggunaan kayu dengan sertifikat lembaga independen seperti LEI atau FRC.

10. Menggunakan material yang menggunakan sistem off site prefabrikasi sebesar minimum $30 \%$ dari total biaya material yang digunakan.

11. Menggunakan bahan material dari dalam negeri.

12. Menggunakan bahan material dari radius $1000 \mathrm{KM}$.

13. Pemilahan sampah organik dan non organik.

Secara keseluruhan dari hasil indetifikasi baru sekitar $45 \%$ prinsip-prinsip Green Building Council Indonesia yang diterapkan pada pembangunan gedung-gedung bertingkat di Kota Kupang.
Secara keseluruhan dari hasil indetifikasi baru sekitar $45 \%$ prinsip-prinsip Green Building Council Indonesia yang diterapkan pada pembangunan gedung-gedung bertingkat di Kota Kupang.

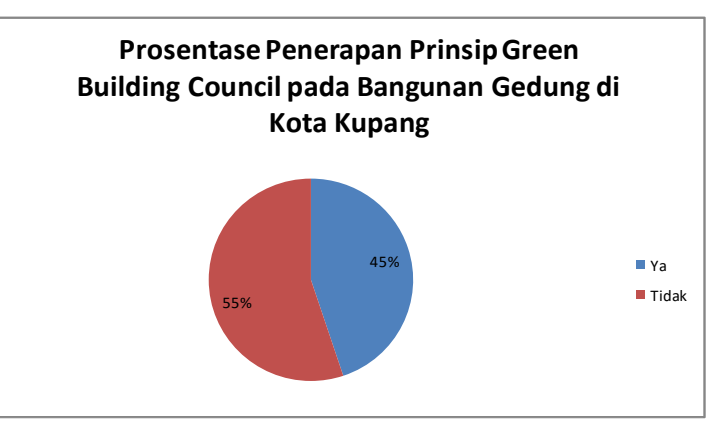

Gambar 5.1. Grafik Prosentase Penerapan Prinsip Green Building

Sumber : Hasil perhitungan

Secara keseluruhan dapat dilihat per unit bangunan gedung yang menerapkan ketentuan dalam Green Building Council Indonesia pada tabel 1 . Kriteria yang paling sedikit diterapkan adalah kriteria penggunaan material lama pada konstruksi bangunan gedung khusus untuk di atas $30 \%$, yaitu $0-7$ unit rumah saja atau sekitar $23 \%$. Hal ini dimaklumi karena umumnya bangunan gedung yang ditinjau adalah rumah toko, perkantoran dan hotel yang lebih banyak menggunakan material baru.

Selain itu, kriteria menggunakan material terbarukan minimum $30 \%$ dari total keseluruhan biaya konstruksi hanya sebesar $17 \%$ atau 5 unit gedung. Umumnya material terbarukan yang dipakai adalah penggunaan kayu untuk rangka atap, kusen pintu jendela dan lantai serta plafon.

Kriteria lainnya yang cukup rendah diterapkan adalah menggunakan material yang proses produksinya memiliki sistem manajemen lingkungan sebesar minimim $30 \%$ dari total biaya material yang gunakan. Umumnya kriteria ini tidak diketahui oleh responden, mengingat tidak ada data yang cukup valid untuk mengetahuinya. Namun setelah ditelusuri, beberapa diantaranya memang telah memenuhi persyaratan di atas. 
\begin{tabular}{l|l|llll} 
& 42 & JUTEKS Jurnal Teknik Sipil Volume 2 & Nomor 1 & April 2017
\end{tabular}

Kriteria penggunaan kayu bersertifikat legal tidak bisa ditunjukkan ( $0 \%)$. Hal ini berarti tidak dan penggunaan kayu dengan sertifikat lembaga terpenuhi. Umumnya kayu yang digunakan independen seperti LEI atau FRC, sama sekali adalah material lokal tanpa sertifikasi.

Tabel 1. Jumlah unit bangunan yang menerapkan prinsip green building khusus untuk material konstruksi

\begin{tabular}{|c|c|c|c|}
\hline \multirow{2}{*}{ No. } & \multirow{2}{*}{ KRITERIA } & \multicolumn{2}{|c|}{ JML UNIT YANG MENERAPKAN } \\
\hline & & Ya & Tidak \\
\hline 1 & $\begin{array}{l}\text { Tidak menggunakan refrigeran HCFC untuk sistem } \\
\text { AC }\end{array}$ & 25 & 5 \\
\hline 2 & $\begin{array}{l}\text { Menggunakan material lama sebesar minimum 15\% } \\
\text { dari total biaya material yang digunakan }\end{array}$ & 23 & 7 \\
\hline 3 & $\begin{array}{l}\text { Menggunakan material lama sebesar minimum } 30 \% \\
\text { dari total biaya material yang digunakan }\end{array}$ & 7 & 23 \\
\hline 4 & $\begin{array}{l}\text { Menggunakan material lama sebesar minimum } 45 \% \\
\text { dari total biaya material yang digunakan }\end{array}$ & 0 & 30 \\
\hline 5 & $\begin{array}{l}\text { Menggunakan material dari sumber terbarukan } \\
\text { sebesar minimum } 20 \% \text { dari total biaya material yang } \\
\text { digunakan }\end{array}$ & 25 & 5 \\
\hline 6 & $\begin{array}{l}\text { Menggunakan material dari sumber terbarukan } \\
\text { sebesar minimum } 30 \% \text { dari total biaya matrial yang } \\
\text { digunakan }\end{array}$ & 5 & 25 \\
\hline 7 & $\begin{array}{l}\text { Menggunakan material yang proses produksinya } \\
\text { memiliki sistem manajemen lingkungan sebesar } \\
\text { minimum } 30 \% \text { dari total biaya material yang digunakan }\end{array}$ & 9 & 21 \\
\hline 8 & Penggunaan kayu bersertifikat legal & 0 & 30 \\
\hline 9 & $\begin{array}{l}\text { Penggunaan kayu dengan sertifikat lembaga } \\
\text { independen seperti LEI atau FRC }\end{array}$ & 0 & 30 \\
\hline 10 & $\begin{array}{l}\text { Menggunakan material yang menggunakan sistem off } \\
\text { site prefabrikasi sebesar minimum } 30 \% \text { dari total biaya } \\
\text { material yang digunakan }\end{array}$ & 12 & 18 \\
\hline 11 & Menggunakan bahan material dari dalam negeri & 30 & 0 \\
\hline 12 & Menggunakan bahan material dari radius $1000 \mathrm{KM}$ & 30 & 0 \\
\hline 13 & Pemilahan sampah organik dan non organik & 9 & 21 \\
\hline
\end{tabular}

Khusus untuk kriteria penggunaan material yang menggunakan sistem off site prefabrikasi sebesar minimum $30 \%$ dari total biaya material yang digunakan dipenuhi oleh 12 gedung yang disurvey atau sekitar $40 \%$. Hal ini umumnya untuk pekerjaan campuran beton umumnya dan rangka atap baja ringan yang umumnya dibuat di pabrik.
Selanjutnya, kriteria menggunakan bahan material dari dalam negeri dan menggunakan bahan material dari radius $1000 \mathrm{KM}$ telah dipenuhi oleh semua bangunan yang disurvey. Akan tetapi, pada kriteria penanganan limbah berupa pemilahan sampah organik dan non organik belum dilakukan dengan sepenuhnya, sekitar $30 \%$ dari sample yang telah secara baik 
melakukan pemilahan sampah organik dan non organik.

\section{Identifikasi Kriteria}

Kriteria yang digunakan diasumsikan diterapkan pada tahap perencanaan, pelak- sanaan dan operasi dan pemeliharaan bangunan. Adapun kriteria yang diakan diuji adalah pada Tabel 2:

Tabel 2. Proses dan Kriteria Pemilihan Material Konstruksi

\begin{tabular}{|l|l|}
\hline \multicolumn{1}{|c|}{ PROSES } & \multicolumn{1}{c|}{ KRITERIA } \\
\hline A. Perencanaan & $\begin{array}{l}\text { 1. Gambar rencana dan spesifikasi teknis sesuai } \\
\text { peruntukan }\end{array}$ \\
\hline $\begin{array}{l}\text { B. Pelaksanaan, Operasi dan Pemeliharaan } \\
\text { Konstruksi }\end{array}$ & $\begin{array}{l}\text { 1. Metode kerja } \\
\text { 2. Penggunaan material lama } \\
\text { 3. Penggunaan material terbarukan } \\
\text { 4. Penggunaan kayu bersertifikat } \\
\text { 5. Penggunaan material off site (prefabrikasi) } \\
\text { 6. Penggunaan material dari radius } 1000 \mathrm{~km} \\
\text { dan berasal dari lokal }\end{array}$ \\
\hline
\end{tabular}

Berdasarkan hasil akhir identifikasi kriteria ini, disusun kuesioner kriteria menggunakan skala Likert kemudian disebarkan kepada responden. Responden yang dituju adalah pemilik bangunan, praktisi kontraktor dan konsultan dan akademisi. Mereka diminta untuk melakukan penilaian terhadap kriteria yang diajukan.
Data hasil survey kemudian diolah dengan menggunakan metode statistik untuk selanjutnya ditetapkan sebagai kriteria yang akan dipakai dalam menilai Penerapan SMM pada Proyek Konstruksi. Uji statistik ini menggunakan bantuan Program SPSS for Windows 12.0

Tabel 3. Hasil Analisa Korelasi Product Moment

\begin{tabular}{|c|l|c|c|c|}
\hline No & \multicolumn{1}{|c|}{ Kriteria } & $\begin{array}{c}\mathrm{r} \\
\text { hitung }\end{array}$ & $\begin{array}{c}\mathrm{R} \\
\text { kritis }\end{array}$ & Ket. \\
\hline 1 & \multicolumn{1}{|c|}{2} & 3 & 4 & 5 \\
\hline A1 & $\begin{array}{l}\text { Gambar rencana dan spesifikasi teknis sesuai } \\
\text { peruntukan }\end{array}$ & 0.913 & 0.482 & Valid \\
\hline B1 & Metode kerja & 0.656 & 0.482 & Valid \\
\hline B2 & Penggunaan material lama & 0.568 & 0.482 & Valid \\
\hline B3 & Penggunaan material terbarukan & 0.845 & 0.482 & Valid \\
\hline B4 & Penggunaan kayu bersertifikat & 0.800 & 0.482 & Valid \\
\hline B5 & Penggunaan material off site (prefabrikasi) & 0.580 & 0.482 & Valid \\
\hline B6 & $\begin{array}{l}\text { Penggunaan material dari radius 1000 km dan berasal } \\
\text { dari lokal }\end{array}$ & 0.656 & 0.482 & Valid \\
\hline
\end{tabular}

Sumber : Hasil Perhitungan 
Sedangkan jika menggunakan nilai $p$-value maka jika $p$-value mempunyai nilai di bawah taraf signifikansi $\alpha$ maka pertanyaan tersebut signifikan atau valid $(p-$ value $<=0,05)$.

Tabel 4. Validitas berdasarkan $p$-value

\begin{tabular}{|c|c|c|c|}
\hline No & Pertanyaan & $p$-value & Kesimpulan \\
\hline 1 & A1 & 0.000 & Valid \\
\hline 2 & B1 & 0.004 & Valid \\
\hline 3 & B2 & 0.017 & Valid \\
\hline 4 & B3 & 0.000 & Valid \\
\hline 5 & B4 & 0.017 & Valid \\
\hline 6 & B5 & 0.000 & Valid \\
\hline 7 & B6 & 0.015 & Valid \\
\hline
\end{tabular}

Sumber : Hasil Perhitungan

Berdasarkan uji data di atas maka terlihat bahwa semua kriteria adalah valid sehingga dapat diikutsertakan dalam analisis.

Selanjutnya, dilakukan uji reliabilitas menggunakan Program SPSS for Windows 12.0 diperoleh koefisien korelasi sebesar 0,940. Koefisien korelasi ini merupakan angka korelasi dari alat ukur yang dibelah, maka angka korelasi yang dihasilkan lebih rendah dari pada angka korelasi yang diperoleh jika alat pengukur tersebut tidak dibelah. Oleh karena itu dicari angka korelasi untuk keseluruhan item tanpa dibelah.

Reliabilitas keseluruhan item diperoleh dengan mengoreksi angka korelasi yang diperoleh dengan memakai rumus Spearmean Brown (Split Half):

$$
\begin{gathered}
r=\frac{2 r_{b}}{1+r_{b}}=\frac{2 \times 0,940}{1+0,940} \\
r=0,9690>\text { koefisien korelasi } 0,940
\end{gathered}
$$

Berdasarkan hasil ini yaitu nilai angka korelasi yang lebih besar dari angka korelasi sebelumnya maka isntrumen penelitian ini reliabel.
Cara lain untuk mengukur reliabilitas adalah dengan mencari koefisien reliabilitas (alpha) menggunakan Program SPSS for Windows 12.0 sebagai berikut :

Tabel 5. Hasil Analisa Reliabilitas Alpha Scale

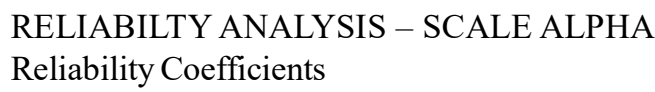

Sumber : Hasil Perhitungan

Dari hasil ini, kesimpulan yang dapat ditarik adalah dengan nilai alpha sebesar 0,9571 sebagai $r$ hasil yang lebih besar dari $r$ korelasi 0,940 maka instrumen yang dipakai dalam penelitian ini adalah reliabel.

Guna mengetahui sebaran tingkat kepentingan dari masing-masing kriteria, menggunakan distribusi frekwensi yang disajikan dalam bentuk grafik histogram

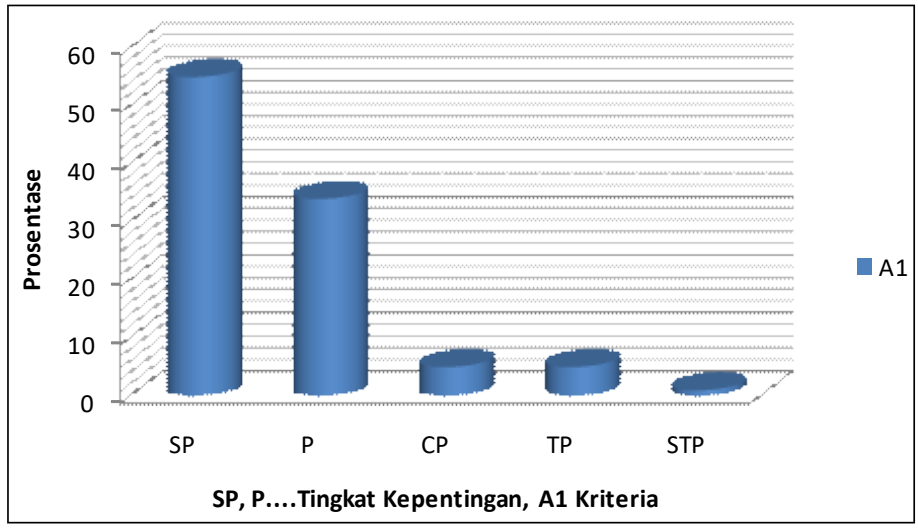

Gambar 1. Frekuensi Kriteria Gambar Rencana dan Spesifikasi Teknis

Dari gambar 1 dapat dilihat bahwa :

- Pada subkriteria A1 responden yang menjawab sangat penting sebanyak $55 \%$, penting $34 \%$, cukup penting $5 \%$ dan tidak penting $5 \%$, sangat tidak penting $1 \%$. 


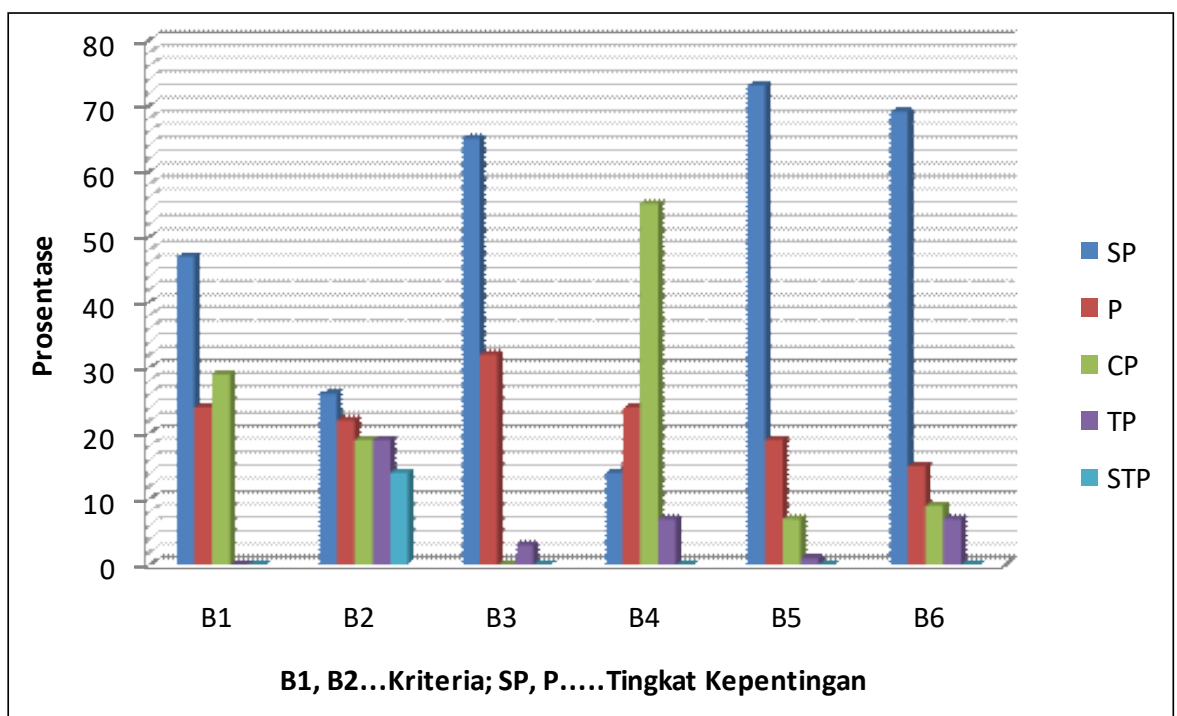

Gambar 2. Frekuensi Kriteria Pelaksanaan, Operasi dan Pemeliharaan Sumber : Hasil olah data

Dari gambar 2 tersebut dapat dilihat bahwa :

- Pada subkriteria B1 responden yang menjawab sangat penting sebanyak $47 \%$, penting $24 \%$, cukup penting $29 \%$

- Pada subkriteria B2 responden yang menjawab sangat penting $26 \%$, penting $22 \%$ dan cukup penting $19 \%$, tidak penting $19 \%$, dan sangat tidak penting $14 \%$.

- Pada subkriteria B3 responden yang menjawab sangat penting $65 \%$, penting $32 \%$ dan cukup penting $0 \%$, tidak penting $3 \%$, dan sangat tidak penting $0 \%$.

- Pada subkriteria B4 responden yang menjawab sangat penting $14 \%$, penting $24 \%$ dan cukup penting $55 \%$, tidak penting $7 \%$, dan sangat tidak penting $0 \%$.

- Pada subkriteria B5 responden yang menjawab sangat penting $73 \%$, penting $19 \%$, cukup penting $7 \%$, tidak penting $1 \%$, dan sangat tidak penting $0 \%$.

- Pada subkriteria B6 responden yang menjawab sangat penting $69 \%$, penting $15 \%$, cukup penting $9 \%$, tidak penting $7 \%$, dan sangat tidak penting $0 \%$.

\section{Uji Hipotesa}

Uji hipotesis terdiri atas uji rata-rata (means) dan uji varians dilanjutkan dengan analisa korelasi berpasangan melalui uji Least Significant Diferent (LSD) bila dalan uji varians menunjukkan adanya perbedaan rata-rata dalam populasi. Nilai rata-rata faktor dihitung dari jumlah nilai total responden terhadap suatu faktor dibagi dengan jumlah responden ;

$$
\sum \text { nilai masing-masing responden }
$$

$$
\text { Means }=\frac{\sum \text { jumlah responden }}{\sum \text { milai masing-masing responden }}
$$

Hasil lengkap perhitungan mean (rata-rata) dapat dilihat pada Lampiran IV.

Teknik statistik yang berhubungan dengan pengujian hipotesis ini berupa analisis varian satu jalan (One Way Anova) terhadap hasil uji means.

\section{Uji Variabilitas}

Uji Variabilitas ini menggunakan test homogeinity of variances untuk menunjukkan perbedaan variabilitas isian setiap faktor. Uji ini menggunakan bantuan Program SPSS for Windows 12.0 . 
Volume 2 Nomor 1 April 2017

Hipotesis yang dipakai adalah sebagai berikut:

Ho $=$ Tidak terdapat perbedaan varian dalam populasi

$\mathrm{H}_{1}=$ Terdapat perbedaan varian dalam populasi

Penarikan kesimpulan :

Jika probabilitas $>0,05$ maka terima Ho

Jika probabilitas $<0,05$ maka tolak Ho.

Dari perhitungan diperoleh hasil bahwa pada masing-masing kriteria nilai siginifikan $>0,05$ yang berarti terima Ho atau tidak terdapat perbedaan varian dalam populasi sehingga dapat dilanjutkan dengan ANOVA.

Tabel 6. Hasil Tes Homogenitas

\begin{tabular}{|l|c|l|}
\hline \multicolumn{1}{|c|}{ Kriteria } & $\begin{array}{c}\text { Signifikansi } \\
0,05\end{array}$ & Keterangan \\
\hline Perencanaan & 0.6644 & Homogen \\
\hline $\begin{array}{l}\text { Pelaksanaan, } \\
\text { Operasi \& } \\
\text { Pemeliharaan }\end{array}$ & 0.0861 & Homogen \\
\hline
\end{tabular}

Sumber : Hasil Perhitungan

\section{Uji Beda Rata-rata}

Uji rata-rata menggunakan ANOVA bertujuan untuk mengetahui apakah semua sampel memiliki rata-rata yang sama. Hipotesis yang digunakan :

Ho $=$ Tidak terdapat perbedaan rata-rata dalam populasi

$\mathrm{H}_{1}=$ Terdapat perbedaan rata-rata dalam populasi

Penarikan kesimpulan dapat dilakukan dengan cara :

1). Berdasarkan perbandingan nilai $F$ hitung dan F tabel

Jika F hitung $>\mathrm{F}$ tabel maka Ho ditolak

Jika $\mathrm{F}$ hitung $<\mathrm{F}$ tabel maka Ho diterima

2). Berdasarkan perbandingan nilai probabilitas

Jika probabilitas $>0,05$ maka terima Ho Jika probabilitas $<0,05$ maka tolak Ho
Dengan menggunakan SPSS 12.0 diperoleh hasil berikut ini :

Tabel 7. Hasil Uji ANOVA

\begin{tabular}{|l|c|c|}
\hline \multicolumn{1}{|c|}{ Kriteria } & $\begin{array}{c}\text { Signifikansi }= \\
0,05\end{array}$ & Keterangan \\
\hline Perencanaan & 0.0468 & Siginifikan \\
\hline $\begin{array}{l}\text { Pelaksanaan, } \\
\text { Operasi \& } \\
\text { Pemeliharaan }\end{array}$ & 0.0100 & Siginifikan \\
\hline
\end{tabular}

Sumber : Hasil Perhitungan

Kesimpulan yang dapat ditarik dari hasil analisa di atas adalah sebagai berikut :

1.Pada kriteria Perencanaan dan Pelaksanaan diketahui nilai siginifikan kurang dari 0,05 yang berarti tolak Ho atau terdapat perbedaan rata-rata dalam populasi sehingga perlu dilakukan uji Lead Significant Different (LSD). Hasil uji ANOVA.

Tabel 8. Hasil Uji LSD Kriteria Perencanaan

\begin{tabular}{|c|c|c|c|}
\hline Sub kriteria & Rata-rata & B2 & B1 \\
\hline A1 & 4.00 & $*$ & $*$ \\
\hline
\end{tabular}

Sumber : Hasil Perhitungan

Dari kriteria fisik, setelah diurutkan rataratanya diperoleh beda rata-rata siginifikan terjadi pada subkriteria B1, dan B2.

Tabel 9. Hasil Uji LSD Kriteria Pelaksanaan, $\mathrm{O} \& \mathrm{P}$

\begin{tabular}{|c|c|}
\hline Sub kriteria & Rata-rata \\
\hline B5 & 4.18 \\
\hline B6 & 4.00 \\
\hline B3 & 3.88 \\
\hline B1 & 3.76 \\
\hline B2 & 3.71 \\
\hline B4 & 3.70 \\
\hline
\end{tabular}

Sumber : Hasil Perhitungan 
Dengan demikian kriteria yang dipakai adalah kriteria yang memenuhi syarat valid, nilai rata-rata (mean) di atas 3,5, jumlah jawaban sangat penting dan penting $>50 \%$, dan beda rata-rata tidak signifikan.

Tabel 10. Kriteria dan Subkriteria

\begin{tabular}{|c|l|}
\hline No & \multicolumn{1}{|c|}{ Kriteria dan Sub kriteria } \\
\hline 1 & \multicolumn{1}{|c|}{2} \\
\hline A & KRITERIA PERENCANAAN \\
\hline A1 & Gambar Rencana dan Spesifikasi Teknis \\
\hline B & KRITERIA PELAKSANAAN, O \& P \\
\hline B5 & $\begin{array}{l}\text { Penggunaan material off site } \\
\text { (prefabrikasi) }\end{array}$ \\
\hline B6 & $\begin{array}{l}\text { Penggunaan material dari radius 1000 } \\
\text { km dan berasal dari lokal }\end{array}$ \\
\hline B3 & Penggunaan material terbarukan \\
\hline B1 & Metode kerja \\
\hline B2 & Penggunaan material lama \\
\hline B4 & Penggunaan kayu bersertifikat \\
\hline
\end{tabular}

\section{KESIMPULAN}

Dari pembahasan di atas dapat diambil kesimpulan sebagai berikut:

1.Penerapan prinsip green construction khusus dalam penggunaan material konstruksi belum sepenuhnya dijalankan secara baik. Hal ini terlihat dari baru sekitar $45 \%$ bangunan bertingkat di Kota Kupang yang menggunakan prinsip green construction building

2.Kriteria-kriteria yang dianalisis dalam penentuan jenis material konstruksi dinyatakan valid dan reliable sehingga dapat dipakai dalam penentuan jenis material konstruksi melalui suatu model pendekatan pengambilan keputusan penentuan jenis material konstruksi.

\section{DAFTAR PUSTAKA}

Ervianto, W. I., 2012, Kajian Aspek Keberlanjutan Material Konstruksi Jembatan Selat Sunda, Makalah Seminar Nasional Teknik Sipil UMS.

Green Building Council Indonesia, 2010, GREENSHIP Homes Rating Tools untuk Rumah Tinggal versi 1.0. Retrieved December 21, 2014 from http://www. greenshiphomes.org/ tabela, A. (2012). Building Materials and The Environment.

Hermawan, dkk, 2013, Peran Life Cycle Analysis (LCA) pada Material Konstruksi dalam Upaya Menurunkan Dampak Emisi Karbondioksida pada Efek Gas Rumah Kaca, Konferesi Nasional Teknik Sipil 7, Uinversitas Sebelas Maret.

Ottong, A. S, dkk, (2014). Penerapan Konsep Sustainable pada Rumah Tinggal dari Segi Material. Surabaya, Indonesia.

Suriptono, 2014, Teknik Sipil. Menghadirkan Konstruksi Hijau. Presentasi Kuliah Umum 12 Maret 2014 di UK Petra, Surabaya.

World Commission on Environment and Development, 1987, Our Common Future, Report of the World Commission on Environment and Development, Development and International Cooperation: Environment August 2, 1987. 